\title{
Validation of the JDS Satisfaction Scales Applied to Educational University Environments
}

\author{
Martha Giraldo-O'Meara ${ }^{1}$, Juan A. Marin-Garcia ${ }^{2}$, Monica Martinez-Gomez ${ }^{3}$ \\ ${ }^{1}$ Universidad Politécnica de Valencia (Spain) \\ ${ }^{2}$ ROGLE-Universidad Politécnica de Valencia (Spain) \\ ${ }^{3}$ Departamento de Estadística e Investigación Operativa. Universidad Politécnica de Valencia (Spain) \\ margiom@upv.es,jamarin@omp.upv.es, momargo@,eio.upv.es
}

Received: July 2013

Accepted: December 2013

\section{Abstract:}

Purpose: The aim of this study is to review and summarize the main satisfaction scales used in publications about human Resource Management and educational research, in order to adapt the satisfaction scales of the Job Diagnostic Survey (JDS) to higher education and validate it with a sample of university students and to assess the concept of satisfaction in two different ways: as a single-item measure, with a global indicator and as a multi-item measure, analyzed as a global model and composed by several scales.

Design/methodology/approach: Confirmatory factor analysis with maximum likelihood, using structural equations model, was employed to assess the model fit in 152 business management undergraduates.

Findings and originality/value: The satisfaction model measured as multi-item scale present an acceptable fit. Even though, some of the satisfaction scales did not present a satisfactory fit, they can be used and interpreted independently with carefulness. Nevertheless, the satisfaction single-item scale presents a better fit and has been validated as a simpler and less costly measure of satisfaction. 
Originality/value In the current process of change that is taking place in universities according to the plan developed by the European Space of higher Education, validated instruments as the satisfaction scale of JDS, adapted to teaching, may facilitate this process through the diagnosis, and follow-up of changes in satisfaction levels in university classrooms.

Keywords: satisfaction, higher education, JDS, university, SEM, EQS

\section{Introduction}

The analogy between the academic world and the enterprise world was proposed over 20 years (Berliner, 1983, en (French \& Chopra, 2006)), however has been in recent years that it has been studied in various disciplines (Freed, 2005; Armstrong, 2003; Donaldson, 2002; Martínez-Gomez \& Marin-Garcia, 2009; O'Neil \& Hopkins, 2002), especially in business management and engineering. This analogy is represented by the possibility of seeing a teacher as a leader who creates the appropriate conditions for learning (Freed, 2005), managing, organizing, and monitoring students achievements (French \& Chopra, 2006). A leader who manages a group of people to develop actions to improve the students "workplace" (Martínez-Gomez \& Marin-Garcia, 2009).

These aspects are related to student motivation and directly influence their satisfaction (Adler, Milne \& Stablein, 2001). However, within the literature on the area, the student satisfaction has traditionally been measured by contextual factors that are not inherently related to the learning process and the quality of teaching (Brennan, Brighton, Moon, Richardson, Rindl \& Williams, 2003; Martínez-Gómez, Carot Sierra, Jabaloyes \& Zarzo, 2011), supported mainly in consumer theory.

Given that job satisfaction questionnaires intend to analyze and determine the aspects or facets that are included and/or related in it taking into account several processes like motivation and, we have not been able to find an instrument that assess student satisfaction through learning, and also identify and facilitate the modification of different aspects of satisfaction, the aim of this study is to adapt and validate to the academic world, a widely used tool in the workplace (Job Diagnostic Survey, JDS) (González, 1997; Hackman \& Oldham, 1980), which has been used to evaluate the motivating potential of the workplace (Freed, 2005; Griffin, 1991), making a diagnosis to determine how they can be redesigned so as to promote the motivation and satisfaction of employees. We pretend to extrapolate these aspects to a sample of students.

This aim is part of a larger study and complex theoretical model of the same instrument (JDS) including job characteristics as a related variable. 


\section{Student satisfaction}

Among the available instruments to measure student satisfaction, the most commonly used are the student satisfaction survey (SSI) (Bryant, 2006; Elliott \& Shin, 2002; Kress, 2006), developed by the American group Noel-Levitz. The University Student's Motivation, Satisfaction, and Learning Self-Efficacy Questionnaire version 3 (TUSMSLSEQ3) (Afzal, Ali, Aslam Khan \& Hamid, 2010), developed by the University of Camberra. The Service Quality Model (SERVQUAL) (Al-Alak, 2009; Arambewella \& Hall, 2009; Douglas \& McClelland, 2007; Standifird, Pons \& Moshavi, 2008), the Student Evaluation of Educational Quality Questionnaire (SEEQ) (Coffey \& Gibbs, 2001), and the "Cuestionario de Satisfacción Académica" (CSA) (Soares, Guisande, Diniz \& Almeida, 2006).

Other instruments with less widespread use, are the Undergraduate Business Exit Assessment (UBEA) (Letcher \& Neves, 2010; Gibson, 2010), the Business Student Satisfaction Inventory (BSSI) (Maddox \& Nicholson, 2008) and the Utrecht Student Monitor (USM) (Möller, 2006). These instruments have been validated in more specific samples and its use is not as widespread as the first ones.

In summary, there are many and varied instruments to measure academic satisfaction (Aldemir \& Gülcan, 2004; Alves \& Raposo, 2009; Beecham, 2009; Chumney \& Ragucci, 2006; DeShields, Kara \& Kaynak, 2005; Douglas, Douglas \& Barnes, 2006; Duque \& Weeks, 2010; Endres, Chowdhury, Frye \& Hurtubis, 2009; Fernández Rico, Fernández Fernández, Álvarez Suárez \& Martínez Camblor, 2007; Gaskell, 2009; Gremler \& McCollough, 2011; Gruber, Fuss, Foss \& Gläser-Zikuda, 2010; Kanno \& Koeske, 2010; Lawrence \& McCollough, 2003; Marozzi, 2009; Parayitam, Desai \& Phelps, 2007; Pascual Gómez, 2007; Pop, Băaccilă, Moisescu \& Jîrca, 2008; Roberts \& Styron, 2010; Van Schaick, Kovacik, Hallman \& Morrison, 2007; Wilson, 2008; Hill \& Epps, 2010; Liu, Borg \& Spector, 2004; Marzo Navarro, Pedraga Iglesias \& Rivera Torres, 2004), however, these instruments are focused primarily on trying to understand the student's perceptions regarding the quality of service offered on campus, the library, classrooms, etc.. (Arambewella \& Hall, 2009), or students surveys for the evaluation of lecturers, the teaching quality or the lecturers' performance and activities (Martínez-Gómez et al., 2011).

\section{Job satisfaction}

The concept of job satisfaction, studied for more than 50 years (van Saane, Sluiter, Verbeek \& Frings-Dresen, 2003), it is one of the most investigated concepts within the human resources area (Kaplan, Warren, Barsky \& Thoresen, 2009; Kinicki, McKee-Ryan, Schriesheim \& Carson, 2002; Oshagbemi, 1999), within the extensive literature on this topic, there are several definitions that can be found. Among them the most common are those of Locke's (1976) 
which describes it as an emotional-affective response to a job or to specific aspects of it, or the Smith's (Smith, Kendall \& Hullin, 1969) where job satisfaction is a feeling or an emotional response to a job facets. However, a theoretically more consistent and more precise definition is that of Weiss (2002), who defines it as an attitude, this is as a "positive or negative, evaluative judgment" towards a job or a situation within this.

Likewise, job satisfaction is made up of two components that define the form in which it will be measured: the cognitive component and the affective component (Kaplan et al., 2009). The affective component refers to the feelings generated for an object, in this case to work, and the cognitive, reflecting the thoughts and beliefs about that object or work. These components may have a correlation between them, but are two independent processes (Weiss, 2002). This distinction is important since it is the theoretical basis from which emerge the instruments that assess job satisfaction.

The vast majority of these instruments are cognitive in nature, focusing on the judgments and beliefs of individuals and do not assess the affective component. The instruments most used to measure job satisfaction are the Job Descriptive Index (JDI) (Stanton, Bachiochi, Robie, Perez \& Smith, 2002; Abdulla, Djebarni \& Mellahi, 2011; Boswell \& Boudreau, 2000); the Minnesota Satisfaction Questionnaire (MSQ) (Weiss, Dawis, England \& Lofquist, 1967; Zeffane, Ibrahim \& Al Mehairi, 2008; Kaplan et al., 2009); The Job Diagnostic Survey (JDS) (Hackman \& Oldham, 1975; Oldham, Hackman \& Pearce, 1976; Kumar, Abbas, Ghumro \& Zeeshan, 2011), and the Warr's Job Satisfaction Scale (WJSS) (Warr, Cook \& Wall, 1979). In the Spanish language, the instruments developed by Meliá \& Peiró, like the S20/23 (Meliá \& Peiró, 1989), are the most used (Sánchez-Anguita, Conde, De la Torre \& Pulido, 2008; Chiang Vega, Salazar Botello \& Núñez Partido, 2007).

In the health sector, there are countless instruments for measuring job satisfaction. Here we have selected one of the most cited as the Mueller McCloskey Satisfaction Scale (MMSS) (van Saane et al., 2003; Ellenbecker \& Byleckie, 2004; Rickard, Roberts, Foote \& McGrail, 2007). Furthermore, in this sector, we found specialized instrument to measure the job satisfaction in nurses as the Nurse Assistant Job Satisfaction Questionnaire (NH-CNA-JSQ) (Castle, 2010), and the Nurses' Job Satisfaction Scale (Ellenbecker \& Byleckie, 2004), among others.

There are other questionnaires which have been used in several studies, but not with the same frequency, such as the Index of Work Satisfaction (IWS) (Jernigan, Beggs \& Kohut, 2002; Manojlovich, 2005); the Multimethod Job Design Questionnaire (MJDQ) (Edwards, Scully \& Brtek, 1999); the Michigan Organizational Assessment Questionnaire (MOAQ) (Spector, Allen, Polemans, LaPierre, Cooper, O'Driscoll, et al., 2007); the "escala general de satisfacción" (NTP 394) (Alonso Martín, 2008; Díaz Echenique, Stimolo \& Caro, 2010); and the International Social Survey Program (ISSP) (Huang \& van de Vliert, 2003). 
Other questionnaires found with a scarce use in the literature are the Jobsat survey (Westover, Westover \& Westover, 2010); the Dubai Job Satisfaction Survey (Abdulla et al., 2011); the Work Motivation and Job Satisfaction Scale (WMJSS) (Saleem, Mahmood \& Mahmood, 2010); the German Job Satisfaction Survey (GJSS) (Liu et al., 2004); the WES-10 (Workplace and Employee survey) (Rossberg, Eiring \& Friis, 2004); the Work Environment Survey (WES) (Houston, Meyer \& Paewi, 2006); the European Employee Index; the Occupational Stress Indicator 2 (OSI2) (Spector \& Fox, 2003); and the "encuesta de satisfacción de las personas", created by "Servicio Vasco de Salud" (Osakidetza) (Robles-García, Dierssen-Sotos, MartínezOchoa, Herrera-Carral, Rosa Díaz-Mendi \& Llorca-Díaz, 2005).

In education, there are the Teaching Satisfaction Scale (Demirtas, 2010; Ho \& Au, 2006), the "Escala de Satisfacción Laboral en la Dirección Escolar" (Tejero-González \& Fernández-Díaz, 2009) and the scale developed by Nicolescu, Dima, Anghel \& Paun (2009). However, these instruments were created to evaluate the satisfaction in teachers and not in students.

Also, there are several instruments to measure the employees satisfaction, which have been developed or applied only in singular studies and little is known about them (Abrajan Castro, Contreras Padilla \& Montoya Ramírez, 2009; Bos, Donders, Bouwman-Brouwer \& Van der Gulden, 2009; Boswell, Boudreau \& Tichy, 2005; Gu \& Chi Sen Siu, 2009; Huang \& van de Vliert, 2003; Kochar, 2008; Mañas, Salvador, Boada, González \& Agulló, 2007; Niklas \& Dormann, 2005; Roelen, Koopmans \& Groothoff, 2008; Ssesanga \& Garrett, 2005; Yang, 2010).

Most of above mentioned instruments are composed of several items grouped into scales that assess different aspects of a job. This is known as multi-item/multi-scale measures, and is one of the ways in which satisfaction is usually measured. The other way is by means of a single indicator that assesses the degree of perceived overall satisfaction (single-item scale) (Oshagbemi, 1999).

Table 1 shows the most used instruments according to the times they have been cited, assessed scales and internal consistency. The most used instrument is the JDS with 4037 cites followed by the JDI (3272), the MSQ (1685), the WJSS (1263), the JSS (609), the MMSS (305), and finally the Spanish questionnaire S20/23, with 68 cites. These instruments are multi-scale measures that assess several aspects of the job, and even though there are many other scales included in the different questionnaires (for instance, the MSQ), the most frequently used in the satisfaction questionnaires are satisfaction with pay, work (from different perspectives), supervision, promotion, co-workers, and to a lesser extent other rewards. 


\begin{tabular}{|c|c|c|c|c|c|c|c|}
\hline & $\begin{array}{l}\text { MSQ } \\
\text { (Weiss, } \\
1967 \text { ) }\end{array}$ & $\begin{array}{c}\text { JDI } \\
\text { (Smith, } \\
\text { 1969) }\end{array}$ & $\begin{array}{c}\text { JDS } \\
\text { (Hackman \& } \\
\text { Oldham, } \\
\text { 1975) }\end{array}$ & $\begin{array}{c}\text { Wjss } \\
\text { (Warr, Cook \& } \\
\text { Wall, 1979) }\end{array}$ & $\begin{array}{c}\text { JSS } \\
\text { (Spector, } \\
1985)\end{array}$ & $\begin{array}{l}\text { S20 } 23 \text { (Meliá } \\
\text { \& Peiró, 1989) }\end{array}$ & $\begin{array}{c}\text { MMSS } \\
\text { (Mueller \& } \\
\text { McCloskey, } \\
\text { 1990) }\end{array}$ \\
\hline $\begin{array}{l}\text { Number of citations } \\
\text { (Extracted from } \\
\text { Google Scholar). }\end{array}$ & 1685 & 3272 & 4037 & 1263 & 609 & 68 & 305 \\
\hline \multicolumn{8}{|c|}{ Scales included } \\
\hline Benefits & & & & & 0.73 & & \\
\hline Pay & 0.91 & 0.80 & $0.82(b)$ & & 0.75 & $\begin{array}{c}0.76-0.89 \\
\text { (satisfaction } \\
\text { with facilities) }\end{array}$ & $\begin{array}{l}0.89(a) \\
\text { (Safety) }\end{array}$ \\
\hline Work & & 0.81 & & & 0.78 & $\begin{array}{c}0.76-0.89 \\
\text { (intrinsic } \\
\text { satisfaction) }\end{array}$ & \\
\hline Promotion & 0.93 & 0.84 & & & 0.73 & $\begin{array}{l}0.76-0.89 \\
\text { (benefits) }\end{array}$ & \\
\hline Supervision & 0.86 & 0.84 & 0.79 & & 0.82 & $0.76-0.89$ & \\
\hline Coworkers & 0.85 & 0.85 & $\begin{array}{l}0.56 \text { (Social } \\
\text { satisfaction) }\end{array}$ & $0.80-0.82$ & 0.60 & & $\begin{array}{l}0.89(\mathrm{a}) \\
\text { (Social } \\
\text { rewards) }\end{array}$ \\
\hline Contingent Rewards & $\begin{array}{l}0.93 \\
\text { (Recog- } \\
\text { nition) }\end{array}$ & & & & 0.76 & & $\begin{array}{l}0.89(\mathrm{a}) \\
\text { (Psychological } \\
\text { rewards) }\end{array}$ \\
\hline Company Policies & 0.90 & & & & & & \\
\hline Communication & $\mathrm{X}$ & & & & 0.71 & & \\
\hline Ability utilization & 0.91 & & & & & & \\
\hline Activity & 0.86 & & & & & & \\
\hline Authority & 0.85 & & & & & & \\
\hline Creativity & 0.87 & & & & & & \\
\hline Growth & & & 0.84 & $\begin{array}{c}\text { 0.82-0.91 } \\
\text { (Higher order } \\
\text { need } \\
\text { strength) }\end{array}$ & & & \\
\hline Independence & 0.85 & & & & & & \\
\hline $\begin{array}{l}\text { Internal work } \\
\text { motivation }\end{array}$ & & & 0.76 & $\begin{array}{c}0.82 \\
\text { (Intrinsic job } \\
\text { motivation) }\end{array}$ & & & \\
\hline Moral values & 0.81 & & & & & & \\
\hline $\begin{array}{l}\text { Operating } \\
\text { Procedures }\end{array}$ & & & & & 0.62 & & \\
\hline Responsibility & 0.78 & & & & & & $\begin{array}{l}0.89(\mathrm{a}) \\
\text { (Psychological } \\
\text { rewards) }\end{array}$ \\
\hline Security & 0.80 & & $0.62(b)$ & & & & \\
\hline Social service & 0.89 & & & & & & \\
\hline Social status & 0.79 & & & & & & \\
\hline Variety & 0.86 & & & & & & \\
\hline Working Conditions & 0.89 & & & $0.58-0.60$ & & $\begin{array}{c}0.76-0.89 \\
\text { (physical } \\
\text { environment } \\
\text { satisfaction) }\end{array}$ & \\
\hline $\begin{array}{l}\text { Perceived intrinsic } \\
\text { job characteristics }\end{array}$ & & & & 0.86 & & & \\
\hline Scheduling & & & & & & & $\begin{array}{c}0.89(\mathrm{a}) \\
\text { (family/work } \\
\text { balance) }\end{array}$ \\
\hline General Satisfaction & & & 0.76 & $\mathrm{X}$ & & & \\
\hline Total life satisfaction & & & & 0.78 & & & \\
\hline Happiness & & & & $\mathrm{X}$ & & & \\
\hline Self-rated anxiety & & & & $0.68-0.74$ & & & \\
\hline
\end{tabular}

Table 1. Satisfaction scales, times cited and internal consistency (Cronbach alpha). (a)Total scale reliability in Van Saane et al. (2003). (b) Indices found in Oldham et al. (1976) 
According to its principal authors, most of the scales presented here show satisfactory reliability indices, except for the co-workers $(0.60)$ and operating procedures $(0.62)$ scales from the JSS, and working conditions (0.58-0.60) from the WJSS, which are slightly below the recommended value (0.70).

There is no agreement on the best way to measure satisfaction. There are several arguments for and against single item or multi-scale/multi-item (Bergkvist \& Rossiter, 2007; Hernández Maestro, Muñoz Gallego \& Santos Requejo, 2008; Oshagbemi, 1999; Marin-Garcia, Bonavia \& Losilla, 2011). On the one hand, single-item scales occupy less space, are less expensive and may be a better measure of job satisfaction change, while the multi-item scales provide more information on the facets of satisfaction, and can be determined their reliability and validity (Nagy, 2002).

In summary, we pretend first, to validate the JDS satisfaction scales adapted to the university teaching version and secondly, to test the satisfaction in two different ways: as a single-item measure (Figure 1a), composed by the S3P03 item and as a multi-factor/multi-item (Figure 1b) composed by the internal work satisfaction, growth satisfaction, satisfaction with grades, satisfaction with security, satisfaction with supervision and social satisfaction as a first order scales with several items each one.

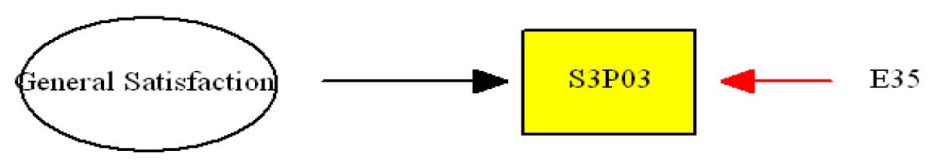

Figure 1a. Satisfaction Models tested. Single-item scale

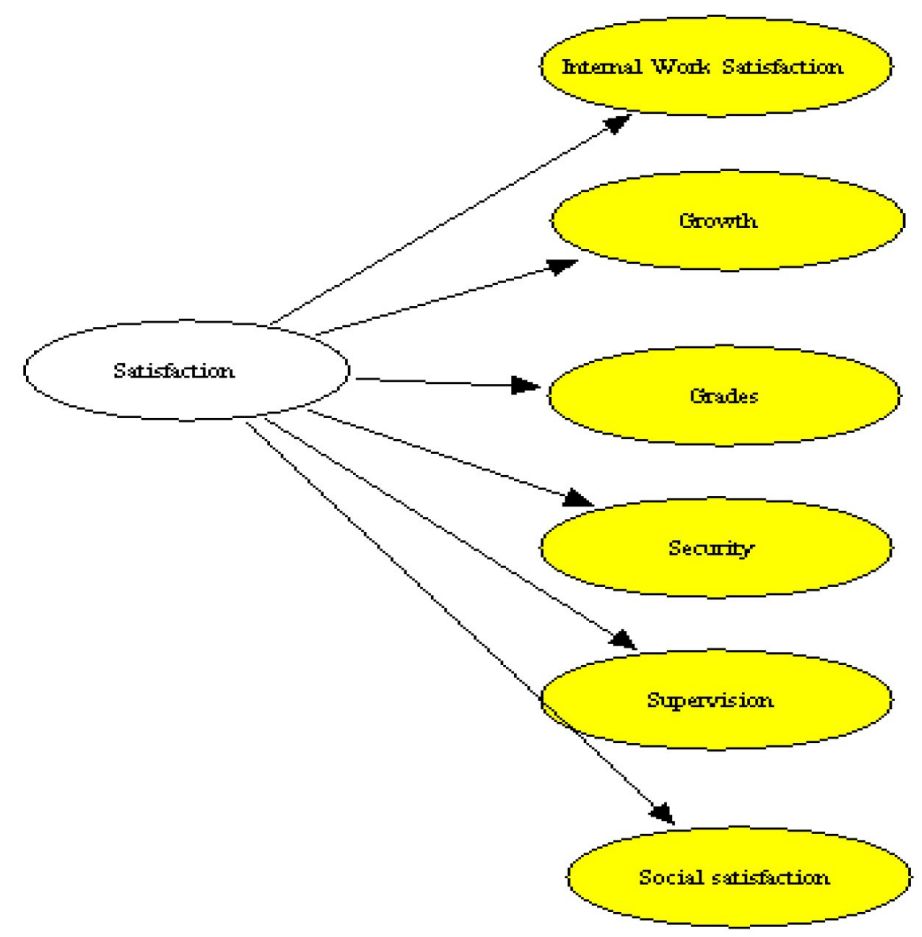

Figure 1b. Satisfaction Models tested. Multi-factor/multi-item scale (items of scales are not included in the diagram) 


\section{Method}

\subsection{Participants}

Data was collected from 152 business management undergraduates, from a public University in Spain, in the 2008-2009 academic year. The data were obtained from 27 different subjects, covering 5 career courses. The instrument was administered directly in the classroom, where the pollster asked volunteers to answer the survey.

\subsection{Measures}

We have used the JDS questionnaire adapted to university teaching (Martínez-Gomez \& MarinGarcia, 2009), based on JDS Spanish version by Fuertes Martinez, Munduate Jaca and Fortea Bagán (1996).

The model consists of four scales that measure the job satisfaction in a seven-points likert scale where higher levels mean more satisfaction. The model scales are: General satisfaction, including one item; internal work motivation, including six items; Growth satisfaction, including 4 items, satisfaction with grades (two items), satisfaction with security (two items), social satisfaction (three items) and satisfaction with supervision (three items). Table 2 presents the scales definitions of the adapted JDS student questionnaire.

\begin{tabular}{|c|c|c|}
\hline Scale & Adapted Definition & Items \\
\hline $\begin{array}{l}\text { General } \\
\text { satisfaction }\end{array}$ & $\begin{array}{l}\text { An overall measure of the degree to which the student is satisfied and } \\
\text { happy with the job. }\end{array}$ & (S3P03) \\
\hline $\begin{array}{l}\text { Internal work } \\
\text { motivation }\end{array}$ & $\begin{array}{l}\text { The degree to which the student is self-motivated to perform effectively } \\
\text { on the job-that is, the student experiences positive internal feelings } \\
\text { when working effectively on the subject, and negative internal feelings } \\
\text { when doing poorly. }\end{array}$ & $\begin{array}{l}{[(\mathrm{S} 3 \mathrm{P} 02)+(\mathrm{S} 3 \mathrm{P} 06)+} \\
(\mathrm{S} 3 \mathrm{P} 10)+(\mathrm{S} 3 \mathrm{P} 14)+ \\
(\mathrm{S} 5 \mathrm{P} 01)+(\mathrm{S} 5 \mathrm{P} 09)] / 6\end{array}$ \\
\hline Growth & $\begin{array}{l}\text { Growth-need strength refers to workers' needs for personal } \\
\text { accomplishment, for learning, and for developing themselves beyond } \\
\text { where they are at present. }\end{array}$ & $\begin{array}{l}{[(\mathrm{S} 4 \mathrm{P} 03)+(\mathrm{S} 4 \mathrm{P} 06)+} \\
(\mathrm{S} 4 \mathrm{P} 10)+(\mathrm{S} 4 \mathrm{P} 13)] / 4\end{array}$ \\
\hline $\begin{array}{l}\text { Satisfaction } \\
\text { with grades }\end{array}$ & $\begin{array}{l}\text { Refers to the degree of satisfaction with basic compensation and benefits } \\
\text { (course marks) as well as satisfaction with the extent to which the } \\
\text { marks relates to the individual's contribution to the organization. }\end{array}$ & {$[(\mathrm{S} 4 \mathrm{P} 02)+(\mathrm{S} 4 \mathrm{P} 09)] / 2$} \\
\hline $\begin{array}{l}\text { Satisfaction } \\
\text { with security }\end{array}$ & $\begin{array}{l}\text { Degree of satisfaction with the amount of general security experienced } \\
\text { to pass the course. }\end{array}$ & {$[(\mathrm{S} 4 \mathrm{P} 01)+(\mathrm{S} 4 \mathrm{P} 11)] / 2$} \\
\hline $\begin{array}{l}\text { Social } \\
\text { satisfaction }\end{array}$ & $\begin{array}{l}\text { The degree of satisfaction with other students with whom contact is } \\
\text { made in the subject, as well as satisfaction with opportunities to get to } \\
\text { know and to help people }\end{array}$ & $\begin{array}{l}{[(\mathrm{S} 4 \mathrm{P} 04)+(\mathrm{S} 4 \mathrm{P} 07)+} \\
(\mathrm{S} 4 \mathrm{P} 12)] / 3\end{array}$ \\
\hline $\begin{array}{l}\text { Satisfaction } \\
\text { with } \\
\text { supervision }\end{array}$ & $\begin{array}{l}\text { The degree of satisfaction with the treatment, support and guidance } \\
\text { received from supervisors (professors), as well as the degree to which } \\
\text { the general quality of supervision is considered satisfactory. }\end{array}$ & $\begin{array}{l}{[(\mathrm{S} 4 \mathrm{P} 05)+(\mathrm{S} 4 \mathrm{P} 08)+} \\
(\mathrm{S} 4 \mathrm{P} 14)] / 3\end{array}$ \\
\hline
\end{tabular}

Table 2. Scales definitions of the JDS university student questionnaire. Source: (Martínez-Gomez \& MarinGarcia, 2009; Marin-Garcia, Martínez-Gómez \& Lloret, 2009) 


\subsection{Analysis}

To analyze convergent validity, the reliability of the scales was assessed by the Cronbach alpha and the compound reliability (greater than 0.7). It also were checked the loads of items and goodness of fit of the confirmatory model, and the extracted variance (greater than 0.5). In order to confirm the discriminant validity, we used the extracted variance versus the squared correlation test (Fornell \& Larcker, 1981) as well as by the correlations confidence interval (Anderson \& Gerbing, 1988).

Confirmatory factor analysis with maximum likelihood, using structural equations model (EQS 6.1 software), was employed to assess how well the data fit the model. Although the size sample is not too large, the statistical $\mathrm{X} 2$ is very sensible to deviations of normality and the size of sample, therefore, other indices have been considered. The Goodness of Fit Index (GFI) and the Adjusted Goodness of Fit Index (AGFI) vary from 0 to 1 and should by equal to or greater than .90 to accept the model. The Comparative Fit Index (CFI) should also be at least .90. Normed fit index (NFI) of Bentler and Bonnet (1980), which varies from 0 to 1 , and values below .90 indicate a need to respecify the model. The index of not-normed adjustment (NNFI) considers the degrees of freedom when dividing the value of the chi-square by the degrees of freedom of the model and must be near to 0.9 for a good adjustment. Also the root mean square of approximation (RMSEA) was analyzed, and measures the amount by which the sample variances and covariances differ from the corresponding estimated variances and covariances. The value should be less than 0.08 (Ullman \& Bentler, 2004). The $\mathrm{R}^{2}$ coefficient (descriptive measure between zero and one, indicating how good one term is at predicting another), was used as a measure in those cases where the goodness of fit indexes cannot be obtained.

\section{Results and discussion}

Table 3 shows the means, standard deviations, skewness and kurtosis measures of the items included in the questionnaire. All items included present average values, except S4P11 (satisfaction with security) by having the lowest mean and S3P06 (internal motivation) whose mean exceeds the value of 5 . All items have sufficient dispersion, with standard deviations between 1.296 (lowest) and 1,902 (highest), that, according to Doval and Viladrich Dieguez Dieguez Segués (Doval Dieguez \& Viladrich Segués, 2011), are acceptable values when the response scale is 1 to 7 .

According to the reliability test (table 4), the Cronbach alpha for all the scales is satisfactory, except in social satisfaction (0.602) where also, items show a low correlation between them $(0.357,0.402$ and 0.481$)$. This happens also in items S3P10, S3P14, S5P01 and S5P09 from the internal motivation scale. 
These results are consistent with those in the Hackman and Oldham's original version, where social satisfaction scale showed a low internal reliability $(0.62)$, meanwhile the other scales presented an excellent reliability.

\begin{tabular}{|c|c|c|c|c|c|c|c|c|c|}
\hline \multirow{2}{*}{ Scale } & \multirow{2}{*}{$\begin{array}{l}\text { Item } \\
\text { code }\end{array}$} & \multicolumn{8}{|c|}{ Descriptive data } \\
\hline & & $\mathbf{N}$ & Range & Min & $\operatorname{Max}$ & Mean & s.d & Skewness & Kurtosis \\
\hline $\begin{array}{l}\text { General } \\
\text { satisfaction }\end{array}$ & S3P03 & 143 & 6.00 & 1.00 & 7.0 & 4.5105 & 1.902 & -0.524 & -0.761 \\
\hline \multirow{6}{*}{$\begin{array}{l}\text { Internal work } \\
\text { motivation }\end{array}$} & S3P02 & 143 & 6.00 & 1.00 & 7.00 & 5.6503 & 1.44991 & -1.590 & 2.417 \\
\hline & S3P06 & 143 & 6.00 & 1.00 & 7.00 & 5.8112 & 1.51030 & -1.714 & 2.656 \\
\hline & S3P10 & 142 & 6.00 & 1.00 & 7.00 & 5.1972 & 1.54937 & -0.997 & 0.402 \\
\hline & S3P14 & 142 & 6.00 & 1.00 & 7.00 & 4.2465 & 1.79513 & -0.220 & -1.027 \\
\hline & S5P01 & 141 & 6.00 & 1.00 & 7.00 & 5.1418 & 1.44707 & -1.026 & 0.730 \\
\hline & S5P09 & 140 & 6.00 & 1.00 & 7.00 & 4.5429 & 1.46602 & -0.308 & -0.425 \\
\hline \multirow{4}{*}{ Growth } & S4P03 & 137 & 6.00 & 1.00 & 7.00 & 4.7080 & 1.52990 & -0.620 & -0.057 \\
\hline & S4P06 & 138 & 6.00 & 1.00 & 7.00 & 5.1304 & 1.52749 & -1.071 & 0.741 \\
\hline & S4P10 & 134 & 6.00 & 1.00 & 7.00 & 4.2015 & 1.55007 & -0.589 & -0.357 \\
\hline & S4P13 & 136 & 6.00 & 1.00 & 7.00 & 4.6691 & 1.56373 & -0.850 & 0.427 \\
\hline \multirow{2}{*}{$\begin{array}{l}\text { Satisfaction } \\
\text { with grades }\end{array}$} & S4P02 & 135 & 6,00 & 1.00 & 7.00 & 4.1037 & 1,70283 & -0.192 & -0.821 \\
\hline & S4P09 & 137 & 6,00 & 1.00 & 7.00 & 4.2044 & 1,65893 & -0.527 & -0.708 \\
\hline \multirow{2}{*}{$\begin{array}{l}\text { Satisfaction } \\
\text { with security }\end{array}$} & S4P01 & 138 & 6,00 & 1.00 & 7.00 & 4.0797 & 1,77189 & -0.242 & -0.872 \\
\hline & S4P11 & 137 & 6,00 & 1.00 & 7.00 & 3.7153 & 1,81476 & -0.122 & -1.071 \\
\hline \multirow{3}{*}{$\begin{array}{l}\text { Social } \\
\text { satisfaction }\end{array}$} & S4P04 & 137 & 6,00 & 1.00 & 7.00 & 5.2993 & 1,29686 & -0.883 & 0.861 \\
\hline & S4P07 & 136 & 6,00 & 1.00 & 7.00 & 4.6471 & 1,38526 & -0.582 & 0.301 \\
\hline & S4P12 & 137 & 6,00 & 1.00 & 7.00 & 4.7664 & 1,45148 & -0.755 & 0.268 \\
\hline \multirow{3}{*}{$\begin{array}{l}\text { Satisfaction } \\
\text { with } \\
\text { supervision }\end{array}$} & S4P05 & 136 & 6,00 & 1.00 & 7.00 & 5.5074 & 1,82978 & -1.282 & 0.583 \\
\hline & S4P08 & 137 & 6,00 & 1.00 & 7.00 & 4.9562 & 1,73573 & -0.745 & -0.272 \\
\hline & S4P14 & 136 & 6,00 & 1.00 & 7.00 & 4.3529 & 1,71066 & -0.448 & -0.532 \\
\hline
\end{tabular}

Table 3. Satisfaction scales Descriptive statistics

\begin{tabular}{|c|c|c|c|c|c|}
\hline Scale & Item & $\begin{array}{l}\text { Item factor loading } \\
\text { in CFA analysis }\end{array}$ & $\begin{array}{l}\text { Squared Multiple } \\
\text { Correlation }\end{array}$ & $\begin{array}{c}\text { Cronbach's Alpha if item } \\
\text { deleted }\end{array}$ & $\begin{array}{c}\text { Cronbach } \\
\text { Alpha }\end{array}$ \\
\hline Genera Satisfaction & S3P03 & 0.869 & 0.740 & 0.738 & n.a. \\
\hline \multirow{6}{*}{$\begin{array}{l}\text { Internal work } \\
\text { motivation }\end{array}$} & S3P02 & 0.802 & 0.633 & 0.773 & \multirow{6}{*}{0.814} \\
\hline & S3P06 & 0.837 & 0.675 & 0.763 & \\
\hline & S3P10 & 0.486 & 0.491 & 0.803 & \\
\hline & S3P14 & 0.512 & 0.550 & 0.794 & \\
\hline & S5P01 & 0.649 & 0.555 & 0.789 & \\
\hline & S5P09 & 0.568 & 0.571 & 0.786 & \\
\hline \multirow{4}{*}{ Growth } & S4P03 & 0.851 & 0.766 & 0.815 & \multirow{4}{*}{0.869} \\
\hline & S4P06 & 0.828 & 0.742 & 0.824 & \\
\hline & S4P10 & 0.648 & 0.607 & 0.878 & \\
\hline & S4P13 & 0.841 & 0.776 & 0.810 & \\
\hline \multirow{2}{*}{$\begin{array}{l}\text { Satisfaction with } \\
\text { grades }\end{array}$} & S4P02 & 0.859 & 0.798 & n.a. & \multirow{2}{*}{0.887} \\
\hline & S4P09 & 0.897 & 0.798 & n.a. & \\
\hline \multirow{2}{*}{$\begin{array}{l}\text { Satisfaction with } \\
\text { security }\end{array}$} & S4P01 & 0.784 & 0.771 & n.a. & \multirow{2}{*}{0.871} \\
\hline & S4P11 & 0.824 & 0.771 & n.a. & \\
\hline \multirow{3}{*}{ Social satisfaction } & S4P04 & 0.750 & 0.481 & 0.406 & \multirow{3}{*}{0.602} \\
\hline & S4P07 & 0.467 & 0.357 & 0.578 & \\
\hline & S4P12 & 0.547 & 0.402 & 0.518 & \\
\hline \multirow{3}{*}{$\begin{array}{l}\text { Satisfaction with } \\
\text { supervision }\end{array}$} & S4P05 & 0.751 & 0.700 & 0.858 & \multirow{3}{*}{0.867} \\
\hline & S4P08 & 0.961 & 0.826 & 0.739 & \\
\hline & S4P14 & 0.781 & 0.719 & 0.838 & \\
\hline
\end{tabular}

Table 4. Internal consistency of satisfaction scales (n.a.= not available) 
Due to the fact that "satisfaction with grades" and "satisfaction with supervision" scales are not identified models, the Cronbach alpha if item deleted and factor loading, could not be calculated.

To check the model validity and reliability, the variance extracted and compound reliability were calculated. The results appear in Table 5. According to the results, the reliability on all scales is above to the cutoff value (0.7), except social satisfaction (0.61). With regard to the extracted variance, internal motivation and especially the social satisfaction (0.36) are below to the recommended value (0.5).

\begin{tabular}{|l|c|c|}
\hline \multicolumn{1}{|c|}{ Scale } & Compound reliability & Extracted variance \\
\hline General satisfaction & n.a. & 0.43 \\
\hline Internal work satisfaction & 0.81 & 0.63 \\
\hline Growth & 0.87 & 0.79 \\
\hline Satisfaction with grades & 0.88 & 0.77 \\
\hline Satisfaction with security & 0.87 & 0.70 \\
\hline Satisfaction with supervision & 0.87 & 0.36 \\
\hline Social satisfaction & 0.61 & n. \\
\hline
\end{tabular}

Table 5. compound reliability and extracted variance (n.a.=not available)

Finally, in table 6 are listed the goodness of fit indices of the model. The growth scale presents an excellent fit with all indices according to recommended values (NFI, CFI, AGFI, GFI = 0.9; RMSEA $=0.08$ ), whereas the internal work motivation scale showed low goodness of fit indices, except for the Goodness-of-fit-index (GFI=0.908). Hence, the models were not identified, the goodness of fit indices of the satisfaction with grades, satisfaction with security, satisfaction with supervision and social satisfaction scales were calculated including into the model analysis, a previously validated, well fit scale. In this case we used the growth scale. Satisfaction with grades, satisfaction with security and satisfaction with supervision scales present a good fit, with adequate values, except for the Adjusted Goodness-of-fit-index (AGFI $=0.784,0.799$ and 0.815 , respectively), and the RMSEA, that it is slightly above of 0.10 .

\begin{tabular}{|l|c|c|c|c|c|c|c|c|}
\hline \multicolumn{1}{|c|}{ Scales } & $\begin{array}{c}\text { No. of } \\
\text { items }\end{array}$ & Chi square & $\begin{array}{c}\text { Freedom } \\
\text { degrees }\end{array}$ & NFI & CFI & AGFI & GFI & RMSEA \\
\hline $\begin{array}{l}\text { General } \\
\text { satisfaction }\end{array}$ & 1 & n.a. & n.a. & n.a. & n.a. & n.a. & n.a. & n.a. \\
\hline $\begin{array}{l}\text { Internal work } \\
\text { satisfaction }\end{array}$ & 6 & 26.849 & 9 & 0.828 & 0.873 & 0.784 & 0.908 & 0.120 \\
\hline Growth & 4 & 2.3039 & 2 & 0.984 & 0.998 & 0.943 & 0.989 & 0.034 \\
\hline $\begin{array}{l}\text { Satisfaction with } \\
\text { grades }\end{array}$ & 2 & 26.1680 & 8 & 0.922 & 0.944 & 0.784 & 0.918 & 0.132 \\
\hline $\begin{array}{l}\text { Satisfaction with } \\
\text { security }\end{array}$ & 2 & 24.3530 & 8 & 0.927 & 0.949 & 0.799 & 0.923 & 0.124 \\
\hline $\begin{array}{l}\text { Satisfaction with } \\
\text { supervision }\end{array}$ & 3 & 31.0782 & 13 & 0.909 & 0.944 & 0.815 & 0.914 & 0.103 \\
\hline $\begin{array}{l}\text { Social } \\
\text { satisfaction }\end{array}$ & 3 & 27.2617 & 13 & 0.896 & 0.941 & 0.856 & 0.933 & 0.092 \\
\hline
\end{tabular}

Table 6.Goodness of fit indices (n.a.= not available) 
The results obtained in the previous statistical analysis, show several problems in the analyzed scales through different tests. In the original adapted scales, the section 5 (S5) items, included in internal work motivation scales, present an R2 very low, which leads to a distortion within them. Same occurs in the items S3P14 and S3P10 within the latter.

Regarding of social satisfaction scale, the scale items show a very low correlation between them (see Table 4), showing a Cronbach's alpha below the recommended value (0.60). Same occurs in the scale reliability compound and variance extracted indices ( 0.61 and 0.36 respectively).

In addition to the results obtained through statistical analysis, semantic analysis of the section 5 items, created several problems in the model, that confirms the findings in the statistical analysis. According to this, we decided to remove those items that did not fit into the model. Therefore, all items of section 5 (S5) were eliminated. These items "ask" for the respondent's believes that their classmates on several aspects of the subject and not the opinion from himself, as in the rest of the questionnaire items. This form of writing, derived from the original questionnaire from Hackman and Oldham (1975), generated confusion among respondents, which altered the scales results.

The social satisfaction scale was eliminated and the items S3P14 and S3P10 (from internal motivation scale) were removed. With these changes, in order to get a more adjusted measurement model, a new structure (respecified mode) (see Figure 2) was created, analyzing the satisfaction measure as second orderfactor (Sat_2ndOrder) composed by the other scales (internal work motivation, growth, satisfaction with grades, satisfaction with security and satisfaction with supervision) measured as multi-item. While social satisfaction scale was eliminated.

The values for the internal work motivation after re-specification present several changes. Because the model is unidentified now, it was estimated using the growth scale. According to the new factor structure, internal work motivation scale showed a good and better fit for the respecified model, than for the original model. As they were not modified, values for satisfaction with growth, satisfaction with grades, satisfaction with security and satisfaction with supervision scales are the same that those in the original model and are showed in table 6.

Regarding of the reliability test, all scales show a Cronbach alpha above the recommended value (see table 8 ). The values obtained in the compound reliability and variance extracted from the general satisfaction measured as single-item scale ( $F C=0.81 ; \mathrm{VE}=0.67$ ), and as multi-item scale (see table 9), are very satisfactory and values are higher than those obtained in the initial model. 


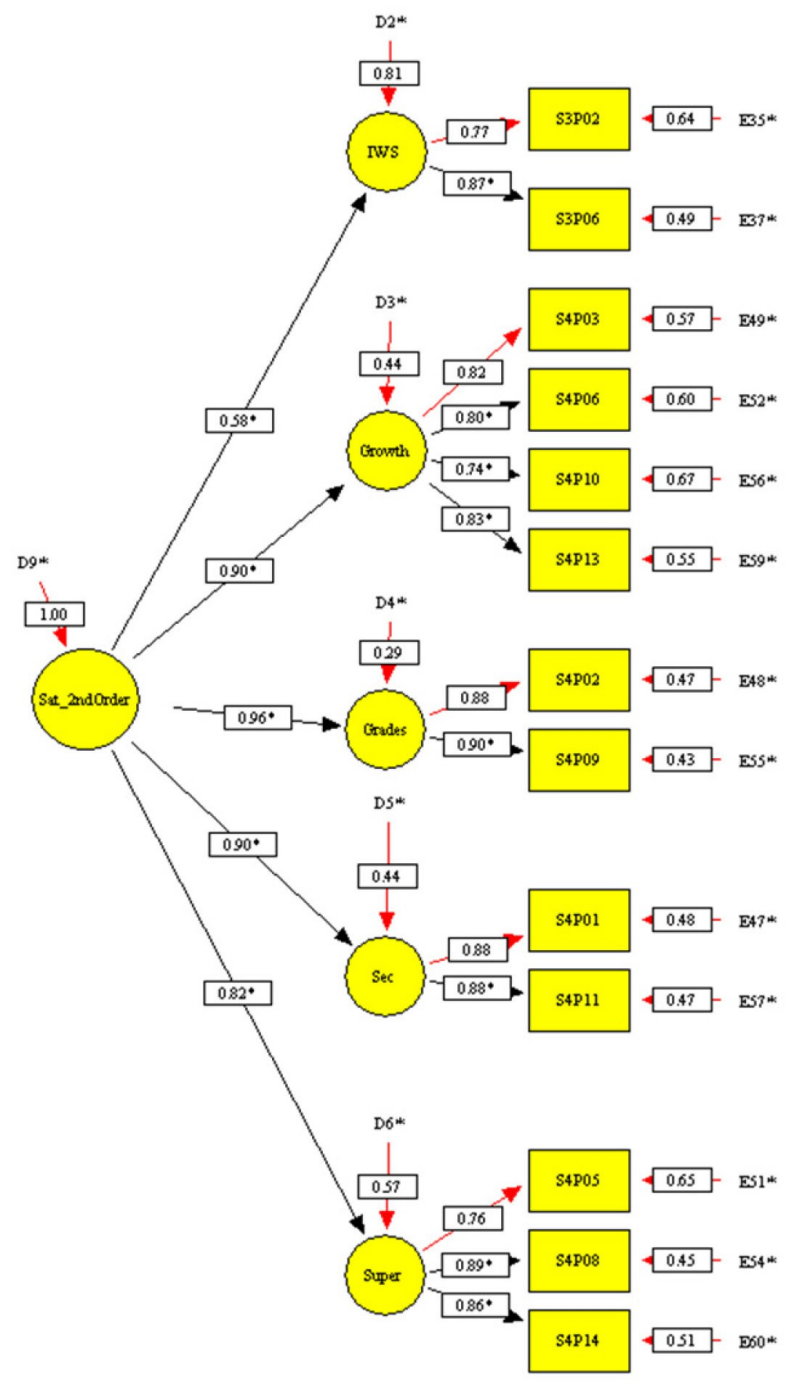

Figure 2. Respecified Model (Sat1 = Satisfaction; IWS = Internal work satisfaction; Grades = Satisfaction with grades; $\operatorname{Sec}=$ Satisfaction with security; Super $=$ Satisfaction with supervision)

\begin{tabular}{|c|c|c|c|c|c|c|c|c|}
\hline Scales & $\begin{array}{l}\text { No. } \\
\text { of items }\end{array}$ & Chi square & $\begin{array}{l}\text { Freedom } \\
\text { degrees }\end{array}$ & NFI & CFI & AGFI & GFI & RMSEA \\
\hline $\begin{array}{l}\text { Internal work } \\
\text { satisfaction }\end{array}$ & 2 & 16.2113 & 8 & 0.921 & 0.957 & 0.849 & 0.942 & 0.088 \\
\hline Growth & 4 & \multicolumn{7}{|c|}{ Scale not modified. Values on table 6.} \\
\hline $\begin{array}{l}\text { Satisfaction with } \\
\text { grades }\end{array}$ & 2 & \multicolumn{7}{|c|}{ Scale not modified. Values on table 6.} \\
\hline $\begin{array}{l}\text { Satisfaction with } \\
\text { security }\end{array}$ & 2 & \multicolumn{7}{|c|}{ Scale not modified. Values on table 6.} \\
\hline $\begin{array}{l}\text { Satisfaction with } \\
\text { supervision }\end{array}$ & 3 & \multicolumn{7}{|c|}{ Scale not modified. Values on table 6.} \\
\hline $\begin{array}{l}\text { Social } \\
\text { satisfaction }\end{array}$ & \multicolumn{8}{|c|}{$\begin{array}{l}\text { Scale eliminated in the respecified model due to the low correlations between scale items, and } \\
\text { reliability compound and variance extracted values below } 0.7 \text { and } 0.5 \text {, respectively. }\end{array}$} \\
\hline
\end{tabular}

Table 7.Goodness of fit indexes of the respecified model 


\begin{tabular}{|c|c|c|c|c|c|}
\hline Scale & Item & Factor loading & $\begin{array}{c}\text { Squared Multiple } \\
\text { Correlation }\end{array}$ & $\begin{array}{c}\text { Cronbach's Alpha if ítem } \\
\text { deleted }\end{array}$ & $\begin{array}{c}\text { Cronbach } \\
\text { Alpha }\end{array}$ \\
\hline \multirow{2}{*}{ Internal work satisfaction } & S3P02 & 0.77 & 0.709 & & \multirow{2}{*}{0.830} \\
\cline { 2 - 6 } & S3P06 & 0.87 & 0.709 & & \\
\hline
\end{tabular}

Table 8. Internal consistency of the respecified model

\begin{tabular}{|c|c|c|c|}
\hline Scale & Number of items & Compound reliability & Extracted variance \\
\hline Internal work satisfaction & 2 & 0.81 & 0.67 \\
\hline
\end{tabular}

Table 9. Scales reliability

Since it is not possible to make a comparison by means of the goodness of fit indices, the comparison of satisfaction as single-item and multi-item scale measures, was made according to the R2 values and the standard error associated with both equations (table 10). Item S3P03 (general satisfaction single-item), explained the greatest variance and presents a smaller standard error. This item successfully represents the general satisfaction as a single-item scale. In the other hand, the satisfaction measured as a second order factor, explain a high proportion of variance, although the internal motivation scale has an R2 below 0.5 (0.34), explaining a very small part of it (see table 10 ).

\begin{tabular}{|c|c|}
\hline Scale & $\mathbf{R} \mathbf{2}$ \\
\hline \multicolumn{2}{|l|}{ Satisfaction single-item scale } \\
\hline S3p03 & 0.96 \\
\hline \multicolumn{2}{|l|}{ Satisfaction multi-item scales } \\
\hline Internal work satisfaction & 0.34 \\
\hline Growth & 0.81 \\
\hline Satisfaction with grades & 0.92 \\
\hline Satisfaction with security & 0.81 \\
\hline Satisfaction with supervision & 0.67 \\
\hline
\end{tabular}

Table 10. Single and multi-item satisfaction scales $\mathrm{R}$ squared

Analyzing the goodness of fit of the satisfaction scale in the re-specified model, as a second order multi-item measure, the values obtained show that despite that they are slightly below the recommended values $\left(X^{2}=132.01\right.$ in $59 \mathrm{g.l}, \mathrm{p}=0.000 ; \mathrm{NFI}=0.84 ; \mathrm{NNFI}=0.87$; CFI $=0.91 ;$ IFI $=0.91 ;$ GFI $=0.81 ;$ AGFI $=0.71 ;$ (RMSEA $=0.098)$, remains a significant model given the large number of parameters to be estimated in the global model versus the number of observations.

Table 11 lists the results of the extracted variance versus squared correlation test (above diagonal) and the correlations confidence interval test (below diagonal). According to these tests, discriminant validity is established among all factors, except among satisfaction with grades and satisfaction with security and satisfaction with growth in the extracted variance versus squared correlation test. 


\begin{tabular}{|l|c|c|c|c|c|}
\hline & $\begin{array}{c}\text { Internal work } \\
\text { satisfaction (F1) }\end{array}$ & Growth (F2) & $\begin{array}{c}\text { Satisfaction with grades } \\
(\mathbf{F 3})\end{array}$ & $\begin{array}{c}\text { Satisfaction with } \\
\text { security (F4) }\end{array}$ & $\begin{array}{c}\text { Satisfaction with } \\
\text { supervision (F5) }\end{array}$ \\
\hline F1 & $\mathbf{0 . 6 7}$ & 0.57 & 0.24 & 0.14 & 0.25 \\
\hline F2 & $(0.38-0.95)$ & $\mathbf{0 . 6 3}$ & 0.68 & 0.62 & 0.56 \\
\hline F3 & $(0.09-0.37)$ & $(0.25-0.74)$ & $\mathbf{0 . 7 9}$ & 0.82 & 0.64 \\
\hline F4 & $(-0.00-0.17)$ & $(0.22-0.68)$ & $(0.28-0.87)$ & $\mathbf{0 . 7 7}$ & 0.47 \\
\hline F5 & $(0.11-0.40)$ & $(0.21-0.65)$ & $(0.23-0.75)$ & $(0.13-0.55)$ & $\mathbf{0 . 7 0}$ \\
\hline
\end{tabular}

Table 11. Discriminant validity

\section{Conclusions}

Instruments used to measure the satisfaction of students are basically focus on assessing aspects related to the quality of the service offered by an institution, the questionnaire JDS can fill a gap in this field (Brennan et al., 2003) making an assessment of satisfaction from a different perspective, where the process of teaching and learning, and students relations with their environment, are its object of analysis and its main objective.

Therefore we propose a new form to assess the students' satisfaction based in the JDS questionnaire. It is important to highlight that JDS has been widely validated in the enterprise world, consequently can be a useful tool for teachers in areas such as human resources and management, allowing them to focus on the process of learning with a more professional view, approaching the student to the professional and working environment. In the same way it allows them to conduct an assessment of the students' perceptions about their class and his role as a teacher.

After statistical analyses and changes made to the initial model based on the problems encountered in a first analysis, the satisfaction model measured by multiple scales present an acceptable fit despite of the fact that the inclusion of several variables generates a quite complex model and as a result, may present some problems like those found in this study.

Even though some of the satisfaction scales presented a good fit, like the internal work satisfaction, growth satisfaction, the satisfaction with supervision and satisfaction with grades, the social satisfaction present poor fit and caution will be needed in the use and the interpretation of them.

Besides, we have been able to validate a single-item measure of satisfaction, simpler, and less costly, according by Nagy (2002). The single-item scale represented by a single item can be a simple but valid alternative to measure the concept of satisfaction. 


\section{Limitations}

This study has used an undergraduates sample, but does not included other populations as a master or PhD students. Besides, the data collected came from just one career degree from a unique university in Spain. Therefore, future studies should use a larger sample including another careers and degrees, in order to amply and generalize the results.

Another limitation of this study is the administration mode of the survey. We used two modes: via a paper questionnaire and via the web. Although Carini, Hayek, Kuh, Kennedy \& Oiumet (2003) reported no differences between both modes, further research into possible mode differences is needed.

\section{Future research}

In future studies, in addition to the above, it would be interesting to analyze the scales that were modified in the present study. An example is the scale of social satisfaction, which did not fit to a global model, and probably should be analyzed as an independent scale in other studies.

Also, since we had operationalized the concept of satisfaction as a reflective model (Diamantopoulos, Riefler \& Roth, 2008), we think this could have generated a misspecification of the model, and therefore, further research is needed wherein the model can be tested with a formative form.

\section{Acknowledgments}

This paper has been written with financial support from the Project "Identificación y baremación de los factores protectores y de riesgo psicosociales en el entorno laboral por medio de un cuestionario adaptado al screening/benchmarking poblacional: implicaciones sobre la calidad de vida laboral" (PAID-05-12-SP20120480) of the Universitat Politècnica de València.

\section{References}

Abdulla, J., Djebarni, R., \& Mellahi, K. (2011). Determinants of job satisfaction in the UAE. A case study of the Dubai police. Personnel Review, 40, 126-146. http://dx.doi.org/10.1108/00483481111095555 
Abrajan Castro, M.G., Contreras Padilla, J.M., \& Montoya Ramírez, S. (2009). Grado de satisfacción laboral y condiciones de trabajo: Una exploración cualitativa. Enseñanza e Investigación en Psicología, 14, 105-118.

Adler, R.W., Milne, M.J., \& Stablein, R. (2001). Situated Motivation: An Empirical Test in an Accounting Course. Canadian Journal of Administrative Sciences, 18, 101-115. http://dx.doi.org/10.1111/j.1936-4490.2001.tb00248.x

Afzal, H., Ali, I., Aslam Khan, A., \& Hamid, K. (2010). A Study of University Students' Motivation and Its Relationship with Their Academic Performance. International Journal of Business and Management, 5, 80-88.

Al-Alak, A.M.B. (2009). Measuring and Evaluating Business Students Satisfaction Perceptions at Public and Private Universities in Jordan. Asian Journal of Marketing, 3, 33-51. http://dx.doi.org/10.3923/ajm.2009.33.51

Aldemir, C., \& Gülcan, Y. (2004). Student Satisfaction in Higher Education: a Turkish Case. Higher Education Management \& Policy, 16, 109-122. http://dx.doi.org/10.1787/hemp-v16-art19-en

Alonso Martín, P. (2008). Estudio comparativo de la satisfacción laboral en el personal de administración. Revista de Psicología del Trabajo y de las Organizaciones, 24, 25-40. http://dx.doi.org/10.4321/S1576-59622008000100002

Alves, H., \& Raposo, M. (2009). The measurement of the construct satisfaction in higher education. The service industrial journal, 29, 203-218. http://dx.doi.org/10.1080/02642060802294995

Anderson, J.C., \& Gerbing, D.W. (1988). Structural Equation Modeling in Practice: A Review and Recommended Two-Step Approach. Psychological Bulletin, 103, 411-423. http://dx.doi.org/10.1037/0033-2909.103.3.411

Arambewella, R., \& Hall, H. (2009). An empirical model of international student satisfaction. Asia Pacific Journal of Marketing and Logistics, 21, 555-569. http://dx.doi.org/10.1108/13555850910997599

Armstrong, M.J. (2003). Students as Clients: A Professional Services Model for Business Education. Academy of Management Learning and Education, 2, 371-374. http://dx.doi.org/10.5465/AMLE.2003.11901964

Beecham, R. (2009). Teaching quality and student satisfaction: nexus or simulacrum? London Review of Education, 7, 135-146. http://dx.doi.org/10.1080/14748460902990336

Bentler, P.M. \& Bonett, D.G. (1980). Significance Tests and Goodness of Fit in the Analysis of Covariance Structures. Psychological Bulletin, 88, 606. http://dx.doi.org/10.1037/00332909.88.3.588 
Bergkvist, L., \& Rossiter, J.R. (2007). The Predictive Validity of Multiple-Item Versus SingleItem Measures of the Same Constructs. Journal of Marketing Research, XLIV, 175-184. http://dx.doi.org/10.1509/jmkr.44.2.175

Bos, J.T., Donders, N.C.G.M., Bouwman-Brouwer, K.M., \& Van der Gulden, J.W.J. (2009). Work characteristics and determinants of job satisfaction in four age groups: university employeesGÇÖ point of view. International Archives of Occupational \& Environmental Health, 82, 1249-1259. http://dx.doi.org/10.1007/s00420-009-0451-4

Boswell, W.R., \& Boudreau, J.W. (2000). Employee Satisfaction with Performance Appraisals and Appraisers: The Role of Perceived Appraisal Use. Human resource development quarterly, 11, 283-299. http://dx.doi.org/10.1002/1532-1096(200023)11:3<283: :AID-HRDQ6>3.0.CO;2-3

Boswell, W.R., Boudreau, J.W., \& Tichy, J. (2005). The Relationship Between Employee Job Change and Job Satisfaction: The Honeymoon-Hangover Effect. Journal of Applied Psychology, 90, 882-892. http://dx.doi.org/10.1037/0021-9010.90.5.882

Brennan, J., Brighton, R., Moon, N., Richardson, J., Rindl, J., \& Williams, R. (2003). Collecting and using student feedback on quality and standards of learning and teaching in higher education. A report to the Higher Education Funding Council for England. Cambridge: Open University.

Bryant, J.L. (2006). Assessing Expectations and Perceptions of the Campus Experience: The Noel-Levitz Student Satisfaction Inventory. New Directions for Community Colleges, 2006, 25-35. http://dx.doi.org/10.1002/cc.234

Carini, R.M., Hayek, J.C., Kuh, G.D., Kennedy, J.M., \& Ouimet, J.A. (2003). College students responses to web and paper surveys: Does Mode Matter? Research in Higher Education Journal, 44, 1-19. http://dx.doi.org/10.1023/A:1021363527731

Castle, N.G. (2010). An instrument to measure job satisfaction of certified nurse assistants. Applied Nursing Research, 23, 214-220. http://dx.doi.org/10.1016/j.apnr.2008.09.005

Chiang Vega, M.M., Salazar Botello, C.M., \& Núñez Partido, A. (2007). Clima organizacional y satisfacción laboral en un establecimiento de salud estatal: Hospital tipo 1. Theoria, 16, 61-76.

Chumney, E.C.G., \& Ragucci, K.R. (2006). Student satisfaction and academic performace in a dual pharmD/MBA Degree Program. American Journal of Pharmaceutical Education, 70, 1-4. http://dx.doi.org/10.5688/aj700229

Coffey, M., \& Gibbs, G. (2001). The Evaluation of the Student Evaluation of Educational Quality Questionnaire (SEEQ) in UK Higher Education. Assessment \& Evaluation in Higher Education, 26, 89-93. http://dx.doi.org/10.1080/02602930020022318 
Demirtas, Z. (2010). Teachers' job satisfaction levels. Procedia Social and Behavioral Sciences, 9, 1069-1073. http://dx.doi.org/10.1016/j.sbspro.2010.12.287

DeShields, O.W., Kara, A., \& Kaynak, E. (2005). Determinants of business student satisfaction and retention in higher education: Applying Herzberg's two-factor theory. International, 19, 128-139.

Diamantopoulos, A., Riefler, P., \& Roth, K.P. (2008). Advancing formative measurement models. Journal of Business Research, 61, 1203-1288. http://dx.doi.org/10.1016/j.jbusres.2008.01.009

Díaz Echenique, M.S., Stimolo, M.I., \& Caro N.P. (2010). Satisfacción Laboral y Síndrome de Desgaste Laboral en Enfermeros de Hospitales Públicos Córdoba-Argentina. Medicina y Seguridad del Trabajo, 56, 22-38. http://dx.doi.org/10.4321/S0465-546X2010000100003

Donaldson, L. (2002). Damn by Our Own Theories: Contradictions Between Theories and Management Education. Academy of Management Learning and Education, 1, 96-106. http://dx.doi.org/10.5465/AMLE.2002.7373701

Douglas, J., Douglas, A., \& Barnes, B. (2006). Measuring student satisfaction at a UK university. Quality Assurance in Education, 14, 251-267. http://dx.doi.org/10.1108/09684880610678568

Douglas, J., \& McClelland, R. (2007). The development of a conceptual model of student satisfaction with their experience in higher education. Quality Assurance in Education, 16, 19-35. http://dx.doi.org/10.1108/09684880810848396

Doval Dieguez, E., \& Viladrich Segués, M.C. (2011). Desarrollo y adaptación de cuestionarios en el ámbito de la salud. Bellaterra: Laboratori d'Estadística Aplicada i de Modelització (UAB).

Duque, L.C., \& Weeks, J.R. (2010). Towards a model and methodology for assessing student learning outcomes and satisfaction. Quality Assurance in Education, 18, 84-105. http://dx.doi.org/10.1108/09684881011035321

Edwards, J.R., Scully, J.A., \& Brtek, M.D. (1999). The measurement of work: Hierarchical representation of the multimethod job design questionnaire. Personnel Psychology, 52, 305-333. http://dx.doi.org/10.1111/j.1744-6570.1999.tb00163.x

Ellenbecker, C.H., \& Byleckie, J.J. (2004). Home Healthcare Nurses' Job Satisfaction Scale: refinement and psychometric testing. Journal of Advanced Nursing, 52, 70-78. http://dx.doi.org/10.1111/j.1365-2648.2005.03556.x

Elliott, K.M., \& Shin, D. (2002). Student Satisfaction: an alternative approach to assessing this important concept. Journal of Higher Education Policy \& Management, 24, 197-209. http://dx.doi.org/10.1080/1360080022000013518 
Endres, M.L., Chowdhury, S., Frye, C., \& Hurtubis, C.A. (2009). The Multifaceted Nature of Online MBA Student Satisfaction and Impacts on Behavioral Intentions. Journal of Education for Business, 84, 304-312. http://dx.doi.org/10.3200/JOEB.84.5.304-312

Fernández Rico, J.E., Fernández Fernández, S., Álvarez Suárez, A., \& Martínez Camblor, P. (2007). Éxito académico y satisfacción de los estudiantes con la enseñanza universitaria. Revista Electrónica de Investigación y Evaluación Educativa, 13, 203-214.

Fornell, C., \& Larcker, D. (1981). Evaluating Structural Equation Models with Unobservable Variables and Measurement error. Journal of Marketing Research, 18, 39-50. http://dx.doi.org/10.2307/3151312

Freed, J.E. (2005). Creating a Total Quality Environment (TQE) for Learning. Journal of Management Education, 29, 60-81. http://dx.doi.org/10.1177/1052562904264283

French, N.K., \& Chopra, R.V. (2006). Teachers as executives. Theory into Practice, 45, 230-238. http://dx.doi.org/10.1207/s15430421tip4503_5

Fuertes Martinez, F., Munduate Jaca, L., \& Fortea Bagán M.Á. (1996). Análisis y Rediseño de Puestos (adaptación española del cuestionario Job Diagnostic Survey). Universidad Jaime I, Castellón.

Gaskell, A. (2009). Student satisfaction and retention: are they connected? Open Learning, 24, 193-196. http://dx.doi.org/10.1080/02680510903201524

Gibson, A. (2010). Measuring business student satisfaction: a review and summary of the major predictors. Journal of Higher Education Policy \& Management, 32, 251-259. http://dx.doi.org/10.1080/13600801003743349

González, L. (1997). Estructura Factorial y Propiedades Psicométricas de la Versión Castellana del "Job Diagnostic Survey" (JDS). Psicológica, 227-251.

Gremler, D.D., \& McCollough, M.A. (2011). Student Satisfaction Guarantees: An Empirical Examination of Attitudes, Antecedents, and Consequences. Journal of Marketing Education, 24, 150-160. http://dx.doi.org/10.1177/027753024002008

Griffin, R.W. (1991). Effects of Work Redesign on Employee Perceptions, attitudes and behaviors: A long-term Investigation. Academy of Management Journal, 34, 425-435. http://dx.doi.org/10.2307/256449

Gruber, T., Fuss, E., Foss, R., \& Gläser-Zikuda, M. (2010). Examining student satisfaction with higher education services. Using a new measurement tool. International Journal of Public Sector Management, 23, 105-123. http://dx.doi.org/10.1108/09513551011022474 
Gu, Z., \& Chi Sen Siu, R. (2009). Drivers of job satisfaction as related to work performance in Macao casino hotel. An investigation based on employee survey. International Journal of Contemporary Hospitality Management, 561-578. http://dx.doi.org/10.1108/09596110910967809

Hackman, J.R., \& Oldham, G.R. (1975). Development of the Job Diagnostic Survey. Journal of Applied Psychology, 60, 159-170. http://dx.doi.org/10.1037/h0076546

Hackman, J.R., \& Oldham, G.R. (1980). Work Redesign. Addison-Wesley.

Hernández Maestro, R.M., Muñoz Gallego, P.A., \& Santos Requejo, L. (2008). Satisfacción con el empleo y su repercusión sobre los resultados en el ámbito del turismo rural. Revista Española de Investigación de Marketing ESIC, 12, 89-114.

Hill, M.C., \& Epps, K.K. (2010). The impact of physical classroom environment on student satisfaction and student evaluation of teaching in the university environment. Academy of Educational Leadership Journal, 14, 65-79.

Ho, C., \& Au, W. (2006). Teaching Satisfaction Scale: Measuring Job Satisfaction of Teachers. Educational and psychological measurement, 6, 172-185. http://dx.doi.org/10.1177/0013164405278573

Houston, D., Meyer, L.H., \& Paewi, S. (2006). Academic Staff Workloads and Job Satisfaction: Expectations and values in academe. Journal of Higher Education Policy and Management, 28, 17-30. http://dx.doi.org/10.1080/13600800500283734

Huang, X., \& van de Vliert, E. (2003). Where intrinsic job satisfaction fails to work: national moderators of intrinsic motivation. Journal of Organizational Behavior, 24, 159. http://dx.doi.org/10.1002/job.186

Jernigan, I.E., Beggs, J.M., \& Kohut, G.F. (2002). Dimensions of work satisfaction as predictors of commitment type. Journal of Managerial Psychology, 17, 564-579. http://dx.doi.org/10.1108/02683940210444030

Kanno, H., \& Koeske, G.F. (2010). MSW students' satisfaction with their field placements: the role of preparedness and supervision quality. Journal of Social Work Education, 46, 23-38. http://dx.doi.org/10.5175/JSWE.2010.200800066

Kaplan, S.A., Warren, C.R., Barsky, A.P., \& Thoresen, C.J. (2009). A note on the relationship between affect(ivity) and differing conceptualizations of job satisfaction: Some unexpected meta-analytic findings. European Journal of Work \& Organizational Psychology, 18, 29-54. http://dx.doi.org/10.1080/13594320701873264 
Kinicki, A.J., McKee-Ryan, F.M., Schriesheim, C.A., \& Carson, K.P. (2002). Assessing the Construct Validity of the Job Descriptive Index: A Review and Meta-Analysis. Journal of Applied Psychology, 87, 14-32. http://dx.doi.org/10.1037/0021-9010.87.1.14

Kochar, B. (2008). Job satisfaction among academics. The Icfai University Journal of Organizational Behavior, VII, 54-60.

Kress, A.M. (2006). Identifying What Matters to Students: Improving Satisfaction and Defining Priorities at Santa Fe Community College. New Directions for Community Colleges, 2006, 37-46. http://dx.doi.org/10.1002/cc.235

Kumar, A., Abbas, Q., Ghumro, I.A., \& Zeeshan, A. (2011). Job characteristics as predictors of job satisfaction and motivation. Asian Journal of Business and Management Sciences, 1, 206-216.

Lawrence, J.J., \& McCollough, M.A. (2003). Implementing Total Quality Management in the Classroom by Means of Student Satisfaction Guarantees. Total Quality Management, 15, 235-254. http://dx.doi.org/10.1080/1478336032000149063

Letcher, D.W., \& Neves, J.S. (2010). Determinants of undergraduate business student satisfaction. Research in Higher Education Journal, 6, 1-26.

Liu, C., Borg, I., \& Spector, P.E. (2004). Measurement Equivalence of the German Job Satisfaction Survey Used in a Multinational Organization: Implications of Schwartz's Culture Model. Journal of Applied Psychology, 89, 1070-1082. http://dx.doi.org/10.1037/00219010.89.6.1070

Locke, E.A. (1976). "The nature and causes of job satisfaction". In M.D.Dunnette (Ed.), Handbook of Industrial and Organizational Psychology (pp. 1297-1343). Chicago, IL: Rand McNally.

Maddox, E.N., \& Nicholson, C.Y. (2008). The business student satisfaction inventory (bssi): development and validation of a global measure of student satisfaction. Developments in Business Simulation and Experiential Learning, 35, 101-112.

Mañas, M.Á., Salvador, C., Boada, J., González, E., \& Agulló, E. (2007). La satisfacción y el bienestar psicológico como antecedentes del compromiso organizacional. (Spanish). Psicothema, 19, 395-400.

Manojlovich, M. (2005). Linking the practice Environment to Nurses' Job Stisfaction Through Nurse-Physician Communication. Journal of Nursing Scholarship, 37, 367-373. http://dx.doi.org/10.1111/j.1547-5069.2005.00063.x 
Marin-Garcia, J.A., Bonavia, T., \& Losilla, J.M. (2011). Exploring working conditions as determinants of job satisfaction: an empirical test among Catalonia service workers. The Service Industries Journal, 31, 2051-2066. http://dx.doi.org/10.1080/02642069.2011.559226

Marin-Garcia, J.A., Martínez-Gómez, M., \& Lloret, J. (2009). Enhancing motivation and satisfaction of students: analysis of quantitative data in three subjects of Industrial Engineering. WSEAS Transactions on Advances in Engineering Education, 6, 11-21.

Marozzi, M. (2009). A composite indicator dimension reduction procedure with application to university student satisfaction. Statistica Neerlandica, 63, 258-268. http://dx.doi.org/10.1111/j.1467-9574.2009.00422.x

Martínez-Gómez, M., Carot Sierra, J.M., Jabaloyes, J., \& Zarzo, M. (2011). A multivariate method for analyzing and improving the use of student evaluation of teaching questionnaires: a case study. Quality \& Quantity, 45, 1415-1427. http://dx.doi.org/10.1007/s11135-010-9345-5

Martínez-Gómez, M., \& Marin-Garcia, J.A. (2009). Como medir y guiar el cambio hacia entornos educativos universitarios más motivadores para los alumnos. Formación Universitaria, 2, 3-14. http://dx.doi.org/10.4067/S0718-50062009000400002

Marzo Navarro, M., Pedraga Iglesias, M., \& Rivera Torres, P. (2004). Tipología de estudiantes en función de su satisfacción con los cursos de verano. Revista Electrónica de Investigación y Evaluación Educativa, 10, 81-96.

Meliá, J.L., \& Peiró, J.M. (1989). El cuestionario de satisfaccion S10/12: estructura factorial, fiabilidad y validez. Revista de Psicologia del Trabajo y de las Organizaciones, 4, 179-187.

Möller, O. (2006). Student satisfaction survey: the Utrecht University approach. Tertiary Education \& Management, 12, 323-328. http://dx.doi.org/10.1080/13583883.2006.9967177

Mueller, C.W., \& McCloskey, J.C. (1990) Nurses' Job Satisfaction: A proposed measure. Nursing Research, 39, 113-117. http://dx.doi.org/10.1097/00006199-199003000-00014

Nagy, M.S. (2002). Using a single-item approach to measure facet job satisfaction. Journal of Occupational \& Organizational Psychology, 75, 77-86. http://dx.doi.org/10.1348/096317902167658

Nicolescu, L., Dima, A.M., Anghel, F., \& Paun, C. (2009). An analysis of job satisfaction at the academic level: A Romanian case study. Global Journal of Business Research, 3, 83-90.

Niklas, C.D., \& Dormann, C. (2005). The impact of state affect on job satisfaction. European Journal of Work \& Organizational Psychology, 14, 367-388. http://dx.doi.org/10.1080/13594320500348880 
O'Neil, D.A., \& Hopkins, M.M. (2002). The Teacher as Couch Approach: Pedagogical Choices for Management Educators. Journal of Management Education, 26, 402-414. http://dx.doi.org/10.1177/105256290202600406

Oldham, G.R., Hackman, J.R., \& Pearce, J.L. (1976). Conditions Under Which Employees Respond Positively to Enriched Work. Journal of Applied Psychology, 61, 395-403. http://dx.doi.org/10.1037/0021-9010.61.4.395

Oshagbemi, T. (1999). Overall job satisfaction: how good are single versus multiple-item measures? Journal of Managerial Psychology, 14, 388-403. http://dx.doi.org/10.1108/02683949910277148

Parayitam, S., Desai, K., \& Phelps, L.D. (2007). The effect of teacher communication and course content on student satisfaction and effectiveness. Academy of Educational Leadership Journal, 11, 91-105.

Pascual Gómez, I. (2007). Análisis de la satisfacción del alumno con la docencia recibida: Un estudio con modelos jerárquicos lineales. Revista Electrónica de Investigación y Evaluación Educativa, 13, 127-138.

Pop, M.D., Băaccilă, M.F., Moisescu, O.I., \& Jîrca, A.M. (2008). The impact of educational experience on students' satisfaction in the romanian higher education system. International Journal of Business Research, 8, 188-194.

Rickard, C.M., Roberts, B.L., Foote, J., \& McGrail, M.R. (2007). Job satisfaction and importance for intensive care unit research coordinators: results from binational survey. Journal of Clinical Nursing, 16, 1640-1650. http://dx.doi.org/10.1111/j.1365-2702.2007.01713.x

Roberts, J., \& Styron, R. (2010). Student satisfaction and persistence: factors vital to student retention. Research Higher Education Journal, 6, 1-18.

Robles-García, M., Dierssen-Sotos, T., Martínez-Ochoa, E., Herrera-Carral, P., Rosa Díaz-Mendi, A., \& Llorca-Díaz, J. (2005). Variables relacionadas con la satisfacción laboral: un estudio transversal a partir del modelo EFQM. Gaceta Sanitaria, 19, 127-134. http://dx.doi.org/10.1157/13074368

Roelen, C.A.M., Koopmans, P.C., \& Groothoff, J.W. (2008). Which work factors determine job satisfaction? Work: A Journal of Prevention, Assessment and Rehabilitation, 30, 433-439.

Rossberg, J.I., Eiring, O., \& Friis, S. (2004). Work environment and job satisfaction: A psychometric evaluation of the Working Environment Scale-10. Social Psychiatry \& Psychiatric Epidemiology, 39, 576-580. http://dx.doi.org/10.1007/s00127-004-0791-z 
Saleem, R., Mahmood, A., \& Mahmood, A. (2010). Effect of Work Motivation on Job Satisfaction in Mobile Telecommunication Service Organizations of Pakistan. International Journal of Business and Management, 5, 213-222.

Sánchez-Anguita, A., Conde, A., De la Torre, A., \& Pulido, M. F. (2008). Ansiedad y satisfaccion laboral en trabajadoras sanitarias. Ansiedad y Estrés, 14, 55-69.

Smith, P.C., Kendall, L.M., \& Hullin, C.L. (1969). The measurement of satisfaction in work and retirement. Chicago: Rand McNally.

Soares, A.P., Guisande, M.A., Diniz, A.M., \& Almeida, L.S. (2006). Construcción y validación de un modelo multidimensional de ajuste de los jóvenes al contexto universitario. Psicothema, $18,249-255$.

Spector, P.E. (1985). Measurement of Human Service Staff Satisfaction: Development of the Job Satisfaction Survey. American Journal of Community Psychology, 13, 693-713. http://dx.doi.org/10.1007/BF00929796

Spector, P.E., \& Fox, S. (2003). Reducing subjectivity in the assessment of the job environment: development of the Factual Autonomy Scale (FAS). Journal of Organizational Behavior, 24, 417-432. http://dx.doi.org/10.1002/job.199

Spector, P.E., Allen, T.D., Polemans, S.A.Y., LaPierre, L.M., Cooper, C.L., O'Driscoll, M., et al. (2007). Cross-national differences in relationships of work demands, job satisfaction, and turnover intentions with work-family conflict. Personnel Psychology, 60, 805-835. http://dx.doi.org/10.1111/j.1744-6570.2007.00092.x

Ssesanga, K., \& Garrett, R.M. (2005). Job satisfaction of University academics: Perspectives from Uganda. Higher Education, 50, 33-56. http://dx.doi.org/10.1007/s10734-004-6346-0

Standifird, S.S., Pons, F., \& Moshavi, D. (2008). Influence Tactics in the Classroom and Their Relationship to Student Satisfaction. Decision Sciences Journal of Innovative Education, 6, 135-152. http://dx.doi.org/10.1111/j.1540-4609.2007.00161.x

Stanton, J.M., Bachiochi, P.D., Robie, C., Perez, L.M., \& Smith, P.C. (2002). Revising the JDI work satisfaction subscale: Insights into stress and control. Educational and psychological measurement, 62, 877-895. http://dx.doi.org/10.1177/001316402236883

Tejero-González, C.M. \& Fernández-Díaz, M.J. (2009). Medición de la atisfacción laboral en la dirección escolar. Revista Electrónica de Investigación y Evaluación Educativa, 15.

Ullman, J.B., \& Bentler, P.M. (2004). Structural Equation Modeling. In M. Hardy \& A. Bryman (Eds.). Handbook of Data Analysis. SAGE. 431-458. 
van Saane, N., Sluiter, J.K., Verbeek, J.H.A.M., \& Frings-Dresen, M.H.W. (2003). Reliability and validity of instruments measuring job satisfaction-a systematic review. Occupational Medicine, 53, 191-200. http://dx.doi.org/10.1093/occmed/kqg038

Van Schaick, L., Kovacik, K., Hallman, K., \& Morrison, S. (2007). Personality as a Potential Predictor of Academic Satisfaction. PSI CHI Journal of Undergraduate Research, 12, 46-50.

Warr, P., Cook, J., \& Wall, T. (1979). Scales for the measurement of some work attitudes and aspects of psychological well-being. Journal of Occupational Psychology, 52, 129-148. http://dx.doi.org/10.1111/j.2044-8325.1979.tb00448.x

Weiss, D.J., Dawis, R.V., England, G.W., \& Lofquist, L.H. (1967). Manual for the Minnesota Satisfaction Questionnaire. Minnesota studies in vocational rehabilitation: XXII.

Weiss, H.M. (2002). Deconstructing job satisfaction Separating evaluations, beliefs and affective experiences. Human Resource Management Review, 12, 173-194. http://dx.doi.org/10.1016/S1053-4822(02)00045-1

Westover, J.H., Westover, A.R., \& Westover, L.A. (2010). Enhancing long-term worker productivity and performance. The connection of key work domains to job satisfaction and organizational commitment. International Journal of Productivity and Performance Management, 59, 372-387. http://dx.doi.org/10.1108/17410401011038919

Wilson, J.H. (2008). Instructor attitudes toward students: Job satisfaction and student outcomes. College Teaching, 56(4), 225-229. http://dx.doi.org/10.3200/CTCH.56.4.225-229

Yang, J.T. (2010). Antecedents and consequences of job satisfaction in the hotel industry. International Journal of Hospitality Management, 29, 609-619. http://dx.doi.org/10.1016/j.ijhm.2009.11.002

Zeffane, R., Ibrahim, M.E., \& Al Mehairi, R. (2008). Exploring the differential impact of job satisfaction on employee attendance and conduct. The case of a utility company in the United Arab Emirates. Employee relations, 30, 237-250. http://dx.doi.org/10.1108/01425450810866514 


\section{Annex}

Definitions of the scales items of the JDS university teaching questionnaire. English and Spanish. Source: (Martínez-Gomez \& Marin-Garcia, 2009; Marin-Garcia et al., 2009). In bold items retained in final model.

\begin{tabular}{|c|c|c|}
\hline Scale & Item code & Adapted Definition \\
\hline $\begin{array}{l}\text { General } \\
\text { satisfaction }\end{array}$ & S3P03 & $\begin{array}{l}\text { Overall, I am very satisfied with this course. } \\
\text { En general, estoy muy satisfecho con esta asignatura }\end{array}$ \\
\hline \multirow{6}{*}{$\begin{array}{l}\text { Internal work } \\
\text { motivation }\end{array}$} & S3P02 & $\begin{array}{l}\text { My opinion about myself improves or increases when I do my job in this } \\
\text { class. } \\
\text { Mi opinión de mi mismo mejora o aumenta cuando hago bien mi trabajo en } \\
\text { esta asignatura }\end{array}$ \\
\hline & S3P06 & $\begin{array}{l}\text { I feel a great satisfaction when I do well the class activities. } \\
\text { Siento una gran satisfacción cuando hago bien las tareas encomendadas } \\
\text { en la asignatura }\end{array}$ \\
\hline & S3P10 & $\begin{array}{l}\text { I feel bad or unsatisfied when I realize I have not done well the class activities. } \\
\text { Me siento mal o insatisfecho cuando me doy cuenta de que no he hecho bien las } \\
\text { actividades de la asignatura }\end{array}$ \\
\hline & S3P14 & $\begin{array}{l}\text { My feelings are greatly affected by how well I perform the class activities. } \\
\text { Mis sentimientos se ven muy afectado por lo bien o mal que desempeñe las tareas } \\
\text { de la asignatura }\end{array}$ \\
\hline & *S5P01 & $\begin{array}{l}\text { Most students taking this course feel a great satisfaction when they complete their } \\
\text { class activities. } \\
\text { La mayoría de los alumnos que cursan esta asignatura sienten una gran } \\
\text { satisfacción cuando completan bien las actividades encomendadas }\end{array}$ \\
\hline & *S5P09 & $\begin{array}{l}\text { Most people who attend this course feel bad or unsatisfied when they do not do } \\
\text { well their work. } \\
\text { La mayoría de las personas que cursan esta asignatura se sienten mal o } \\
\text { descontentos cuando no realizan bien su trabajo }\end{array}$ \\
\hline \multirow{4}{*}{ Growth } & S4P03 & $\begin{array}{l}\text { The degree of achievement and personal development that I get doing the } \\
\text { class activities. } \\
\text { El grado de realización y de desarrollo personal que obtengo al realizar las } \\
\text { actividades de la asignatura }\end{array}$ \\
\hline & S4P06 & $\begin{array}{l}\text { The sense of growth that I get when I do my work. } \\
\text { El sentimiento de autorrealización que obtengo al hacer mi trabajo }\end{array}$ \\
\hline & S4P10 & $\begin{array}{l}\text { The degree of independence of ideas and action I can have. } \\
\text { El grado de independencia de ideas } y \text { acción que puedo ejercer }\end{array}$ \\
\hline & S4P13 & $\begin{array}{l}\text { The extent to which my activities as a student are stimulant. } \\
\text { La medida en que mis actividades como estudiante son estimulantes }\end{array}$ \\
\hline \multirow[b]{2}{*}{$\begin{array}{l}\text { Satisfaction } \\
\text { with grades }\end{array}$} & S4P02 & $\begin{array}{l}\text { The grade I get. } \\
\text { La nota que recibo }\end{array}$ \\
\hline & S4P09 & $\begin{array}{l}\text { The extent to which my contribution to the class activities is adequately } \\
\text { rewarded with grades. } \\
\text { La medida en que mi contribución en las actividades de la asignatura está } \\
\text { bien recompensada con notas }\end{array}$ \\
\hline \multirow[b]{2}{*}{$\begin{array}{l}\text { Satisfaction } \\
\text { with security }\end{array}$} & S4P01 & $\begin{array}{l}\text { Degree of security that I pass the course. } \\
\text { Grado de seguridad de aprobar la asignatura }\end{array}$ \\
\hline & S4P11 & $\begin{array}{l}\text { The security I feel about the possibility of getting a high note in the } \\
\text { course. } \\
\text { La seguridad que siento respecto a la posibilidad de sacar nota alta en la } \\
\text { asignatura }\end{array}$ \\
\hline \multirow{3}{*}{$\begin{array}{l}\text { Social } \\
\text { satisfaction }\end{array}$} & S4P04 & $\begin{array}{l}\text { The people I talk to and work in the class. } \\
\text { La gente con la que hablo y trabajo en la asignatura }\end{array}$ \\
\hline & S4P07 & $\begin{array}{l}\text { The opportunity to meet other people while doing activities. } \\
\text { La oportunidad de conocer otras personas mientras realizo las actividades }\end{array}$ \\
\hline & S4P12 & $\begin{array}{l}\text { The opportunity to help other students while doing my activities. } \\
\text { La posibilidad de ayudar a otros compañeros mientras hago mis actividades }\end{array}$ \\
\hline
\end{tabular}




\begin{tabular}{|c|c|c|}
\hline Scale & Item code & Adapted Definition \\
\hline \multirow{3}{*}{$\begin{array}{l}\text { Satisfaction } \\
\text { with supervision }\end{array}$} & S4P05 & $\begin{array}{l}\text { The degree of respect and fair treatment I receive from my teacher. } \\
\text { El grado de respeto } y \text { el trato justo que recibo de mi profesor }\end{array}$ \\
\hline & S4P08 & $\begin{array}{l}\text { The degree of guidance or support I get from my teacher. } \\
\text { El grado de orientación o de apoyo que recibo de mi profesor }\end{array}$ \\
\hline & S4P14 & $\begin{array}{l}\text { The overall quality of the supervision I receive from my work. } \\
\text { La calidad global de la supervisión que recibo de mi trabajo }\end{array}$ \\
\hline \multirow{4}{*}{$\begin{array}{l}\text { Items included } \\
\text { in JDS but not } \\
\text { included in the } \\
\text { original version } \\
\text { of the adapted } \\
\text { JDS to } \\
\text { Student's } \\
\text { satisfaction }\end{array}$} & S3P09 & $\begin{array}{l}\text { I rarely think about not to attend class. } \\
\text { Pocas veces pienso en dejar de asistir a clase }\end{array}$ \\
\hline & S3P13 & $\begin{array}{l}\text { Overall, I am satisfied with the kind of activities I do in this course. } \\
\text { En general, estoy satisfecho con el tipo de actividades que realizo en esta } \\
\text { asignatura }\end{array}$ \\
\hline & *S5P02 & $\begin{array}{l}\text { Most of the people who attend this course are very satisfied with their work. } \\
\text { La mayoría de las personas que cursan esta asignatura están muy satisfechas con } \\
\text { su trabajo }\end{array}$ \\
\hline & *S5P08 & $\begin{array}{l}\text { People who attend this class rarely think about not to attend school } \\
\text { Las personas que cursan esta asignatura pocas veces piensan en dejar de asistir a } \\
\text { clase }\end{array}$ \\
\hline
\end{tabular}

*Section five (S5) statement. Now think about your CLASSMATES. Answer in terms of how you think they feel. Ahora piensa en tus COMPAÑEROS DE CLASE. Responde en función de cómo crees que ellos/as se sienten.

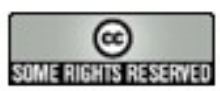

Article's contents are provided on a Attribution-Non Commercial 3.0 Creative commons license. Readers are allowed to copy, distribute and communicate article's contents, provided the author's and Journal of Industrial Engineering and Management's names are included. It must not be used for commercial purposes. To see the complete license contents, please visit http://creativecommons.org/licenses/by-nc/3.0/. 